\title{
Balochi Folklore
}

\section{Longworth Dames I.C.S. M.R.A.S.}

To cite this article: M. Longworth Dames I.C.S. M.R.A.S. (1902) Balochi Folklore, Folklore, 13:3, 252-274, DOI: 10.1080/0015587X.1902.9719308

To link to this article: http://dx.doi.org/10.1080/0015587X.1902.9719308

$$
\text { 曲 Published online: } 06 \text { Feb } 2012 .
$$

6 Submit your article to this journal ๘

Lll Article views: 1

Q View related articles ¿ 


\section{BALOCHI FOLKLORE.}

BY M. LONGWORTU DAMES, I.C.S, (retired), M.R.A.S.

\section{(Read at Meeting of 28th May, 1902.)}

THE Balochi race is spread over a wide extent of country, from the valley of the Indus in Sindh and the Panjab to the southern part of the province of Kirmãn in Persia, and occupies a great portion, though not the whole, of the intervening country shown on our maps under the name of Balochistan. I do not intend, on this occasion, to enter into questions relating to its ethnological affinities, but will merely state that it appears to belong to the old Iranian stock, and that the Balochi language is certainly an Iranian dialect. The branch of the race with which I am concerned is that inhabiting the mountain country west of the Indus Valley, and spreading into the plains of the country known as the Derajat, and especially those tribes which still retain the use of the Balochi language. I must confess that my collections of materials were made originally mainly for purposes of philology, and only indirectly for reasons more strictly connected with folklore. I was very anxious especially to preserve from destruction, while it was still possible, the remnants of the popular poetry of the Baloches before it disappears from the world along with their language, and I am happy to think that I met with some success in this object. I also took down, without modification or doctoring, a number of stories in prose, and translations of about twenty of these were published some years ago in "Folk-Lore." I am glad to say that the collection of poems has now been taken up by the Rev. T. J. M. Mayer, of Dera Ghazi Khan, and I hope that we have succeeded in rescuing the greater

I Vol. iii., 517 ; vol. iv., 195, 285, 518; vol. viii., p. 77. 
portion of the heroic ballads, as well as a good deal of more modern poetry. These ballads are the most valuable material for the legendary history of the race. They date probably for the most part from the early part of the sixteenth century, and relate mainly to the last great migration of the Baloches which led them to their present positions. Some of the prose narratives are also derived from ballads, and occasionally embody fragments of poems which are now lost. There is less foreign influence in these than in the majority of the prose stories, which are evidently to a great extent borrowed from Persian or Indian neighbours; picked up, perhaps, in the bazaars of Kalät, Quetta, Shikārpur, or Dera Ghazi Khan, from Persians at Bampur, Arabs at Gwădar, Panjäbi soldiers at Räjanpur or Bombay sepoys at Jacobabad.

The ballads, though never hitherto written down, yet have a distinct style of their own which may be called literary; and new ones are still composed and sung on the old pattern. There is a stock of poetical or archaic words and phrases which are not used in the language of common life, but which inevitably appear in the war-ballad or the love-song. Every tribe has attached to it a few families, called by the Indian name Dom or the Persian Lori, who are not Baloches by blood or in features, but live among them and speak their language. The Doms are of Indian origin, probably aboriginal. Among the Baloches the tribal Dom quite identifies himself with the tribe, and sings their war-songs with great spirit. But the Doms do not themselves make the ballads. The poets are invariably pureblooded Baloches, but it is not consistent with their dignity to sing them in public, so the poet always gets a Dom to whom he teaches the words. The Dom sings them in public to the accompaniment of the dambiro or sarinda. Both of these are stringed instruments, the dambiro being playedgwith the fingers like a guitar, while the sarinda, a more elaborate instrument with six or seven gut strings, 
is held upright like a violoncello, and played with a horsehair bow. ${ }^{\text {I }}$

Another instrument, the nar or pipe, is used for accompanying the short love-songs known as dastannagh, to which I shall allude later. The style of singing with the nar accompaniment is peculiar to the hill-tribes. The singer and player sit on the ground with their heads close together, and the singer drops his voice to the pitch of the instrument, which seemed to me to be an octave below the natural voice. He takes a long breath and sings the whole song through in one breath, ending with a deep gasp when exhausted, the voice seeming to proceed from the stomach. The effect is very peculiar, but not at all disagreeable, and the accompaniments are very pleasant embroideries on the original air. This style of singing is never used for the long ballads, which are accompanied on the stringed instruments.

The poem often begins with an invocation to the minstrel, addressed as "sweet singing Lori," to bring forth his instrument and sing; the instrument being alluded to by the name of the wood it is made of, either the phäpugh (Tecoma) or the Shägh (Grewia). Then the song com. mences a ballad, perhaps of recent tribal wars or one of the old heroic ballads of the Balochi Iliad, the great thirty years' war between the Rinds and Lasharis over the fair Gohar, the Helen of the tale. She was the mistress of great herds of camels, and Mir Chäkar, the Rind Chief, and Gwaharăm, the Lashäri Chief, contended for her hand. Gohar preferred Chäkar, and there was wrath among the Lashäris, but the final outbreak was brought about by the incident of the horse-race. 'Two young chiefs, one on each side, backed their mares for a prize, a fat sheep belonging to a Mochi, and the Rinds by trickery made out that their champion had won. It is worth notice, that though most of the

The sarinda sometimes has sympathetic wires under the gut strings, like the Indian sårangt. 
ballads reach us from a Rind source, it is always admitted that the Rinds acted dishonestly on this occasion. The Lashäris went off in wrath, and some hot-headed young men, coming across Gohar's herd of female camels with their young ones, killed some of the young camels. As they came back in the evening, the female camels in their distress stirring up the dust, the milk dripping from their udders, Chäkar also arrived at Gohąr's tents. He asked what had happened, and Gohar tried to put him off, saying that the young camels had died from eating poison bushes; but he quickly got the truth out of the herdsman, and swore an oath to take revenge on the Lashäri, to "gamble with hair and heads and turbans." So the war began, and lasted for thirty years, till the " teeth dropped from their heads." The Rinds bad ultimately the worst of it, and Chäkar led them to the Panjab, where other tribes had already gone before. Another set of ballads deals with the wars which took place there, and their attack on Delhi with Humäyann. There is a certain amount of real history mixed up with all this. Chảkar was a real leader of the Baloches, and was living in Humäyün's time, but history does not tell us whether the Baloches took part in his expedition to recover his kingdom. If they did, it is evident that their share in it was not quite so important as their poems represent it. Chākar figures in the ballads as a man of wonderful powers : we are told how he fought with an elephant, having no weapon except a dog which was lying asleep in the road; and other surprising adventures. He looked back on Sibi from a hill still called Chăkar-Mări, although Sibi is not really visible from it; he was fleeing through the Chäkartankh, or Chäkar's defile, with a herd of buffaloes, which were turned into stones to obstruct his enemies. They are still to be seen in the form of boulders scattered about the pass.

There is perhaps a mythological element in some of the stories, which may go back to pre-Muhammadan times. 
Nodhbandagh, father of Gwaharam, is the Giver, the goldscatterer, the typical generous man, who made holes in his money-bag, so that every one might pick up the gold, and gave all his clothes to a ragged Dom, taking his old shirt in exchange. This shirt he divided into two parts, one for his wife and one for himself. In the night a laden camel came and sat down in front of his tent. He told his wife to go out and smell the camel, as if it had a pleasant smell, and not the ordinary smell of a camel, it was sent from heaven; and so it was. The camel was laden with garments of every kind both for man and woman. The name Nodhbandagh is an almost literal translation of the Greek "cloud-compeller," and it is impossible not to suspect that we have here a fragment of some forgotten mythology. Nodhbandagh's son was Gwaharăm, one of the heroes of the poems, and his name represents in Balochi the Middle Persian Varahrän, that is the Avestic Verethraghna, the Vritrahan or Indra of the Veda, the deity of the stormcloud.

Some of the ballads go further back than the sixteenth century, and profess to account for the origin of the Baloches, who are said to be descended from Mir Hamza, uncle of the prophet Muhammad, and to have their commencement at Halab, or Aleppo. Mir Hamza was married to a Peri, who saw him while he was bathing in a lake, but their child was for some reason abandoned in the wilderness, whence the story-tellers derive the name Baloch from bar, wilderness, and luch, naked, i.e., naked in the wilderness. This bit of popular etymology is, perhaps, not of great antiquity, and the old ballads do not mention the Peri, but simply say that the Baloches are descended from Mir Hamza. A more interesting story relates to their adventures in Sistān, where historical traces of their presence may be found from the tenth century onwards. They were well received by the King Shamsuddin, but another king demanded brides from them, one from each of the forty-four 
clans of which they then consisted. This was an insult to the Baloches. (Even in the nineteenth century the Khosas went to war rather than give a bride to the Nawăb of Bahāwalpur.) So they temporised, and sent forty-four boys dressed as girls to the king. As they were still young they were made over to the care of nurses, but as they grew up in the king's zenana, the king's suspicions were raised, and the nurses in charge of the boys were put to the question by an original and, I believe, unique method. They were clothed in leathern shalwarrs, or trousers, loose garments fastened tight at the ankles, and inside these cats were turned loosel The eldest of the boys, to save them, then made a clean breast of it on receiving the king's promise of pardon. The king kept his word, and sent the bays back to their clans, but immediately pursued them with all his forces. He was, however, defeated, and their exodus to Mekrān was safely accomplished. There they had a great chief named Jaläl Khản, who had four sons and one daughter who have given their names to the five principal divisions of the race. The story goes that Rind, the eldest son, had been appointed heir by his father and proceeded to perform the funeral ceremonies by erecting an $\bar{a} s r o k h$, or platform; but Hot, the second son, refused to join him, and started a separate ceremony for himself. Thereupon the others followed suit, "and there were five asrokhs in Kech." The forty-four clans distributed themselves, some joining one and some another, and hence the five great tribes: Rind, Lashäri, Hot, Korai, and Jatoi, to one of which nearly all the modern tribes trace their descent.

Thus we find a reproduction in madern times of the fiction of descent from an eponymic ancestor, for there can be little doubt that the tribal names are older than those of their supposed ancestors. Many so called patronymics are in reality either local names like Lashäri, from the country called Lüshār, or nicknames like Rind, a vagabond. The bards of each modern tribe delight to trace the genealogy 
of their chiefs to the heroes of the ballads, and many stories are told to account for the names the tribes now bear. For instance, the Legharis are said to be descended from a Rind named Koh-phrosh, or Stone-crusher, from his strength. In the course of the war with the Lasharis, a number of Lashãri women who had been taken captive by the Turks were made over to Chākar for safe custody, and he arranged for their protection in accordance with Balochi custom (for up to the present day in tribal warfare the Baloches respect and protect women and children). Chäkar every night set a trustworthy warrior to guard the women, but Koh-phrosh betrayed his trust, and was accused by the women in the morning. Chäkar then said that henceforth he was not to be called Koh-phrosh but Leghär, i.e., foul or dirty. It is hardly necessary to state that the Legharis do not admit the truth of this story. They do admit that Leghār was a nickname bestowed upon their ancestor by Chäkar, but say it was an honourable appellation, given to Koh-phrosh when he came out of the fight covered with blood and dust. Two other tribes, the Drishaks and Gishkhauris, are said to be descended from warriors who were placed on guard over the same women, who distinguished themselves by holding up the roof of the shed in which the women were, when it threatened to collapse in a storm. Drishak is said to mean "strong man" (in some unknown tongue, not Balochi), and Gishkhaur is said to mean "house-post," although there can be little doubt that in reality it is a territorial name, from the Gishkhaur, the name of a stream. The Lunds are similarly said to be descended from 'Ali, a relation of Mir Chäkar. He stole the water from an embankment which Chäkar had thrown across a stream to water his crops, and turned it on to his own ficlds. When called to account, he replied, "I only broke your embankment to feed your oven," i.e., to supply Chăkar's kitchen with food; on which Chākar said, "You are a great idiot" (Lund). 
One legend as to the origin of the Gurchanis represents that a certain Hot, who was with Mir Chakkar, went out to hunt the wild ass in the desert, but met with no success He, however, found a child in the desert and brought him home. The women called to him to know whether he had killed a wild ass, on which he pointed to the child and said, "This is the wild ass" (in Balochi, "Gor esh"). Hence the child was called Gorish, and the Gorishanni or Gurchäni are his descendants. Most legends, however, represent this Gorish as a descendant of Doda and a branch of the Dodãi tribe. Doda was a King of Sind of the Somra tribe (for this there is probably a historical basis). He was driven out of his country and had to swim across the Indus, and came half frozen to the tents of Sälhe, a Rind, who, to revive him, put him between the blankets with his daughter Mudho. Sãlhe afterwards gave Doda his daughter in marriage, and adopted him as a Baloch, although he was a Rajput. It is somewhat remarkable that a real Somra Doda, King of Sindh, lost his kingdom and had to flee across the Indus, and a remarkable story, evidently of folklore origin, is told of his adventures by the chroniclers. ${ }^{1}$ It is perhaps allowable to identify the legendary Baloch Doda with this personage.

A few names suggest what is possibly a totemic origin, although I cannot offer any definite opinion on this point Two sections of the Durkãnis bear such names, viz., Szãhphädh, or Blackfeet, and Gandu-gwälagh, or small red ants. The Mazäri tribe (meaning Tiger's sons) has perhaps some such origin. It is noticeable that the device on the banner of the Baloches, as mentioned in Firdausi's great poem, the Shahnama, written at the end of the tenth century, was a tiger.

- Sometimes the ballads turn on religion, and tales of the saints are told, or legends of the celebrated shrines. The

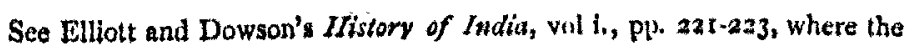
whole story is given. 
best known of these shrines is that of Sakhi Sarwar, which, though situated in country now occupied by Baloches, is certainly of Indian origin, and goes back to the days, perhaps, of the Buddhists ; certainly long before the Baloches had entered the country. The Mujäwirs or custodians of the shrine are Panjābis, not Baloches, and Hindūs as well as Muhammadans still resort to it. The shrine has been often described, and I shall not here give any account of it, as it is not really Baloch. The Baloches, however, venerate it, and have made Sakhi Sarwar into one of their national saints. They connect him with the Holy Prophet 'Ali, and tell a legend to the effect that 'Ali, with his slave, Kambar (i.e "the coloured man"), was once travelling with a caravan of camels laden with gold, when a blind mendicant by the wayside asked him for bread. 'Ali told Kambar to give him bread, but Kambar replied that it was impossible, as the bread was in a bale forming part of a camel's load. Then 'Ali said, "Give him the camel and its load." "But," said Kambar, "it is the leading camel of the string." 'Ali said, "Then give him the whole caravan." At this Kambar was so startled that he fell off his camel's back. 'Ali laughed at him and said, "Oh, Kambar, why do you bury your noble countenance in the dust?" Kambar replied, "In my youth my parents told me that I was the household slave of my lord's horse Duldul, and now, seeing your generosity, I was astounded, fearing lest I, with the other gifts, might be sent wandering in the desert with faqirs." So the beggar received the whole caravan, and his sight was restored, and afterwards he emulated 'Ali's generosity, and became known as "Sakhi Sarwar," the Generous Lord. At one time he was persecuted and had to flee from his enemies along the parched-up country at the foot of the Sulaiman Hills where water is scarce. Whenever he needed water, he drove his staff into the sand, and at those points (such as Choti Bala) fresh water may always still be found by digging in the sandy beds of the torrents. Once while 
riding with a party of Baloches along one of the long narrow valleys or tokhs, which run parallel to the main range of the mountains between the upheaved strata of sandstone, we passed an abundant spring, a rare thing in those parts; but it was salt and undrinkable. A little way off we came to a flat sheet of sandstone, from a small hole in the centre of which fresh water was trickling; and I was told that this place was known as Nezagh-Khushta, or "struck by the spear," for Sakhi Sarwar, on coming to this spot and finding that the spring was salt, drove his spear in wrath into the rock, and the fresh water immediately flowed forth. Not many miles from this spot is Zinda Pir, or the "Living Saint," so called because there Sakhi Sarwar, like Elijah. finally disappeared from the earth, without having aied. The place is marked by a hot sulphur-spring, and the saint's influence makes this beneficial to rheumatic subjects.

The story of the hawk and the pigeon is of a decidedly Buddhist complexion. 'Ali had just been saying his prayers when a hawk struck down a pigeon in front of him. The pigeon appealed to him for protection, but the hawk said: "Oh, my Lord 'Ali, King of men, I left my young ones starving beyond the seven seas at the top of the deep rooted tree, and I have long been seeking some booty to satisfy their hunger. Do not take my only capture from me." Then the pigeon said: "Oh, my Lord 'Ali, my sad state is this, I left my starving children on the cliffs of Mount Bambor, and was pecking a few grains to take to them, when I was seized by this monster, who will slay me, Do not give me to this voracious hawk, for thou art lord of all." Then 'Ali called to Kambar for his knife, and plunged it into his thigh, saying to the hawk, "Come, I will give you flesh to eat," and with that he cut a piece from his thigh, equal in size to the pigeon, or even larger! Then the pigeon burst into tears, saying: "He is not a hawk, nor am I a pigeon, we are Angels of God sent to try you, and well have you borne the test." 
In various narratives, persons who wish to obtain the favour of the saint, go to the shrine and labour at fetching water for the pilgrims. Bālăch did this when his relations had been exterminated by the Bulethis. (I may mention that at Sakhi Sarwar there is only one well, zoo feet deep, and to supply many thousands of pilgrims with water is no easy task.) After three years the saint appeared to Bālāch in a dream, and told him to get a bow. At night he left his bow unstrung, but in the morning he found it strung, and the saint said: "Now thy bow is strung, go and fight thy enemies" ; which he did with great effect. ${ }^{1}$ In the same way, when Samri was carried off by Muhabbat Khān of Kilat, her husband went to the shrine of Jive Lal at Sehwãn in Sindh, and fetched water for the pilgrims, until the saint told him what he was to do. ${ }^{2}$ This shrine, called Läl Shāhbāz as well as Jive Làl, is also much resorted to by Baloches. A description of it is given by Sir Richard Burton in Sind Revisited."

A more modern shrine, now much resorted to, is that of Sulaimān Shāh of Taunsa Sharif. This Saint was a Jaāfir, one of the aboriginal tribes of the mountains, which have resisted absorption by both Baloch and Pathan; and a fine white marble domed shrine has been in recent times erected to his memory. This is a strictly Muhammadan shrine of the nineteenth century, and not like the others, a relic of pre-Muhammadan religions. Perhaps the only shrine sacred to a thoroughly Baloch saint is Pir Sohri, situated at Sohri Khushtagh (i.e., Sohri's slaughter) in the country of the Bughti tribe. Sohri was himself a Bughti, and bestowed his only goat on the four companions of Muhammad, who presented themselves to him disguised as beggars. In recompense, he found a miraculous flock of goats in his enclosure, and was also given the power of finding water

I Folk-Lore, vol. iv., 201.

Folk-Lore, iv., sig.

- Sind Revisited, I877, ch. xxv. 
everywhere by thrusting his staff into the ground. U1timately his head was cut off by his enemies, but he took it in his hands and pursued them until they made restitution, when he finally died. Offerings of goats are still made at his shrine. In the wildest part of the country of the Bozdar tribe I once came across a small shrine to a local saint. Around the tomb a number of large fossil shells had been placed, which were held sacred. I was in favour with the Bozdars just then, as I had succeeded in settling some old feuds among them, and the Chief of the tribe, who was with me, solemnly presented me with two of these shells, which I still have.

These Bozdars are among the wildest and least sophisticated of all the Baloch tribes. The ordeal by fire still prevails among them, and the Chief once reported a case to me officially, asking for sanction to the proceedings. A man had been accused of theit, and offered to clear himself by the fire-ordeal. A trench was filled with burning charcoal, and he had to walk along it from end to end. He did this, but his feet were burnt, and his accusers said that this proved his guilt; but the Chief and all the head men of the tribe held that this was immaterial, and that the real test was to walk from end to end without climbing out of the trench on either side. As there was no evidence whatever against the man, I concurred.

$\mathrm{An}$ allusion to the ordeal by fire will be found in the story of Naina Bai." The test was somewhat different from that in the Bozdar case. Naina Bai had to clear herself of an accusation of being false to the king, her lover. She, too, had to walk from end to end of a trench filled with live charcoal, but as she really had been false it was necessary to circumvent the ordeal. Her actual lover accordingly disguised himself as a half-witted faqir, and just as she was

'See the whole story in Iletri Ran's Bilichi Nama (Doule's translation, Calcutta, 1885), p. 77.

* Folk-Lore, iv, 290. 
about to enter the fire he threw his arms round her, calling out to the king not to burn such a beautiful woman. Naina Bai acted on the hint given her, and swore that she had never been embraced by any man save the king and this mad beggar. This was literally true, as the beggar was her lover, and apparently the oath was quite satisfactory to the powers which preside over ordeals, for she went through unscathed and was cleared. In neither case does the ordeal seem to have been quite a trustworthy test of guilt or innocence.

Belief in omens, in divination by soothsayers, in the casting of lots, and in witches, is very general. One of the omens which I have most frequently noticed refers to the black and white shrike, or giyanchh. If this bird is seen on the left-hand side on starting, the omen is inauspicious, and the party will often turn back and make a fresh start. It is supposed to mean bloodshed, perhaps the death of one of the party. But if hunting or shooting is the object of the expedition it is all right, as blood is what is wanted, and the shrike on the left-hand means good sport. The left is always the unlucky side. $A$ bad omen is always called chapi, that is left-hand, or sinister. The soothsayer, or augur, is a well-known institution. Men who have this gift are known as rammali. The augury is generally made by inspecting the blood-vessels on the shoulder-blade of a sheep (hinjri or bardast) just after it is killed. For drawing lots, dried goat's or sheep's dung is generally used. Every man drawing, marks his own piece with his nails so as to recognise it.

It may be said, as a general statement, that the Muhammadan religion, though nominally followed, has not much effect on the wilder and nomadic Baloches. Sayyids and Mulläs are not found everywhere, as among the Afghans; on the contrary, they are hardly known except among the more settled tribes. The oath on the $Q u r^{\prime} a \bar{n}$ is, however, 
regarded with great awe, and is much more binding than among most Muhammadan races.

The aversion of the Baloches to fish is certainly not part of the Muhammadan religion. The fish is generally believed among Musalmāns to be hatal, or lawful, without the ceremony of throat-cutting with the words "bismi 'lalh" necessary in the case of all other lawful animals. The gills of the fish are believed to be specially provided as an equivalent for the throat-cutting. The Baloch, however, will not eat fish, or touch it with his hands if possible, a fact by which the angler profits greatly. Eggs are avoided also by Baloches, as carrion, for although they contain life they cannot be killed in the legal manner. I do not think, however, that this is universal.

The superstition about the mamm, or black bear, is, I believe, peculiar to the Baloches, although of course it is akin to the wer-wolves, tigers, \&c., of other countries. It is difficult to get the people to speak about it freely, but I ascertained that the mamm frequently takes the form of a beautiful woman at night, and hugs men to death if they are not wary; but by day it is never seen except as a bear.

I have not come across any cases of persons recognised as wizards or witches, although such no doubt exist. In the stories the däen, or witch, is a well-known institution. She is a woman who obtains magical powers by digging up and devouring dead bodies at night.

Sacred trees are occasionally found among the Baloches, as throughout India, and are occasionally hung with rags, bits of the clothes of the passers-by. This custom may possibly be borrowed from the other tribes with whom the Baloches have been in contact.

A universal custom is the erection of cairns (chedhagh) to mark the site of any memorable event, a fight, a murder, a banquet, \&c. Passers-by often add stones to these cairns. The word chedhagh, or chedag, as it is pronounced in Mekrün, 
is perhaps descended from the Buddhist Chaitya, to which it seems to correspond according to etymological rules. Another kind of cairn is known as a dambul. This is a cairn of mockery, erected in scorn of some contemptible action, something contrary to the nammüdh or Baloch code of honour. I remember once seeing a pile of stones in the Chāchar Pass and asking what it commemorated. After some hesitation and a good deal of laughter I was told it was a $d a m b u l$ put up against a certain chief of a neighbouring tribe who had proved faithless, and turned back from an expedition on which he had set out.

Tombs in the hill country are much more elaborate and permanent than houses. The grave is generally covered with a pile of stones arranged in lines, black and white alternately, and these stones are often carried long distances. The chiefs' tombs are masses of masonry, solidly built, and the more wealthy and civilised chiefs erect elaborate monuments. Nawab Sir Imam Bakhsh Khan Mazâri has built a group of domed tombs covered with blue and white Multan tiles, which will compare favourably with anything of the sort I have seen built in modern times in Northern India. The habit is an old one, for the tomb of Ghazi Khan Dodai at Churatta, of about the year A.D. 1550, is a fine octagonal brick building in the Persian style, with remains of coloured tiles.

I once saw a tomb erected to a dog-at least there was a legend to that effect. This was in the country of the Marris, and the story told me was that of a dog and a wolf, almost identical with the Beddgelert story. This is certainly remarkable, as the Indian version of the story, found in the Hitopadesa, contains nothing about a dog and a wolf, but a mungoose and a snake figure in it.

Among the more settled Baloches the position of women is much the same as among other Muhammadan races. The principal men have zenanas, and the women do nut appear in public, but this restriction is not strictly observed among 
the less wealthy, and among the hill-tribes a good deal of liberty is allowed. One of the customs is for the women to form bands, to which no man is admitted, and to roam about the nountains together. They are never molested, and one of the most honourable characteristics of the Baloches is that they never kill or otherwise molest women or children in their raids. A boy may not be killed until he has been formally declared to be a man by being invested with the Baloch equivalent of the toga virilis, that is, the shalwär or baggy trousers worn by men. This garment he assumes at the age of about fifteen. He is then a man, and may legitimately be killed.

Any insult to women is gravely resented. I once met with a case among the Lashäris. Two men had a quarrel, and one of them went to the other's hut in his absence, found only his mother there, and insulted her by tearing off her phashk, or bodice. Her son thereupon challenged him to fight. A spot was appointed, and each came to the rendezvous with one companion. They were armed with swords and shields, but threw away their shields and carved at each other with their swords as long as they could stand. I heard of the fight, but too late to prevent it, and after a twenty-mile ride through a fiery hot wind I arrived in time to see two corpses and two wounded men being carried into the little frontier fort of Sabzilkot. They had fought on the bare smooth plain, known as patt, a little way from the fort, and the ground was saturated with their blood.

In quite recent years a desperate feud between the Leghäri and Gurchäni tribes followed upon an insult in connection with a breach of promise of marriage put upon the Chief of the Gurchannis. This Chief had a blot in his pedigree, owing to his father's mother having been a dancing-girl. His own mother was Baloch, but he was still not quite reinstated as of the true blood, and was very anxious to get a bride of good family. He succeeded at length in getting 
betrothed to a relation of the Leghări Chief; but at the last moment the engagement was broken off, and the girl married to a Leghāri living in Bahāwalpur across the Indus. This Leghāri was promptly killed by some Gurchānis and a renegade Leghäri, and although the Chief's complicity could not be proved, there was no moral doubt of it; and it was so generally believed that I found it necessary to recommend Government to deprive him of his powers as a magistrate and judge-a very serious matter with the chief of a tribe. War broke out between the independent sections of the tribes living in the hills, and years passed before the affair had blown over. Even now I should not be surprised to hear of its breaking out afresh. Feuds regarding women are frequent and severe, and are difficult to deal with. Love among the Baloches is, I believe, more spiritual and less gross in its manifestations than among most Oriental races, and the tone of the numerous lovepoems is often of a genuinely romantic character. I may allude to the story and poem of Dostèn and Shiren, of which I have published a translation; ${ }^{1}$ the poems of Jam Durrak, some of which also I have translated ; Réhãn's lament over the death of Salo and Bivaragh's love-song, both translated by the Rev. T. J. Mayer ${ }^{8}{ }^{\text {and others still }}$ untranslated which I have in MS.

The little poems called dastãnagh, of a few lines only, which are sung to a flute accompaniment, are often of this type. The following are a few examples, but I need not say that they lose a great deal in translation:

Wandering maid, I am on thy track, For three years past I am on thy track, I am lame with wandering on thy track, A pain in my breast, I am on thy track. A fool in my heart, I am on thy track, IIopeless in soul, but on thy track.

' Folk-Lord, vol. viii., p. 79.

Sketch of North Balochi Language, 1881.

* Balochi Classics, pp. 13 and 15. 
Friends, give me flowers for my hair And take my messnge to Sherän. My golden ring for my finger bring And give me flowers for my hair. Give me my fine camel-saddle And the fine scalbard of my sword. Come to the well to draw water And take iny message to my love, "I am thy slave with joined hands."

My ring is on thy finger, do not now go back, With thy beautiful hair, do not now go back, Thy pledge is on my finger, do not now go back. And thou wast never false, do not now go back.

Janari is my soul!

If she be old, she is my soul, If she be far off, she is my soul. Thy head is mine, 'tis on my soul, Thy head is mine, do not be sad, Thy head is mine, I am not sad, I am not sad when thou art with me, To see thee move, I am not sad, To look on thee, I am not sad.

I trusted in thee, false one ! I made thee my love, false one, Give back my pledge, fatse one ! May'st thou be blind, false one, Mays't thou go lame, false one, Maimed of thy hands, false one ! No fault was mine, false one $!$

Marriage is an affair of contract; and where girls are bought and sold without any regard to their own consent it is inevitable that most of the love-affairs should be with married women, and that the husband should be regarded as an enemy to be got rid of. This feeling is found in the songs, and sometimes takes a comic form.

Tie up your husband with a rope, and come to your tryst,

Tie the rope to a log, and come to your tryst,

Throw the $\log$ into the river, and come to your tryst.

Ile watches you by day, put on your shoes,

Girl with the hair, and come to your tryst I 


\author{
Sãvi's husband must be caught, \\ He must be caught, he must be beaten, \\ Ile must be sent for a ride in the train, \\ And put into the Sibi gaol. \\ The barber must be sent for, \\ His beard clipped and his hair shorn, \\ And only his skin left him to rub, \\ And then let him get a new wife!
}

This was no doubt composed when the railway to Sibi was first made and the gaol opened by the British Government. The unfortunate husband is to be entrapped and sent to prison, where he will have his hair cut off. It is a national custom among the Baloches never to cut hair or beard, except to trim the moustache as a sign of orthodoxy. (The Balochi's orthodoxy consists of little else !) It is a great disgrace to have the hair cut; so much so that in the Dera Ghazi Khan gaol the rule about cutting the hair is suspended in favour of Baloches, as it is in favour of Sikhs in other places.

Another little song, which is invariably greeted with great laughter, has for its burden-

"Aunt, the child's cap is lost I"

Where the lady who wishes to meet her lover is trying to find an excuse for getting out of the house at night, and pretends that she has dropped her boy's cap, and must go out to look for it.

It need hardly be added that elopements are very frequent. The Baloch code of honour is very severe, and demands that the husband should kill his wife and her lover, and this he must do without waiting for proof, if it even comes to his knowledge that her name has ever been mentioned in connection with that of another man, in however casual a way. The consequence is that the woman and her lover always elope as soon as they can, and escape into the territory of another tribe or clan. If the lover belongs to this other clan his cause is espoused by his fellow-clansmen, and even if he does not belong to it, the laws of hospitality 
forbid the surrender of refugees. If one of the fugitives is slain in the territory of another clan, a blood-feud may probably be started. There is, however, a remedy in pecuniary compensation, which our administration has utilised and reduced to a system in the management of these wild tribes. The woman is regarded as a piece of property, worth four or five hundred rupees, stolen by one tribe or clan from another, and compensation may be accepted without loss of honour-compensation in kind if possible, but estimated in cash terms. Thus it may be arranged that the fixed sum is to be paid by the injuring to the injured party, but in fact money seldom passes. A suitable bride is given by the defendant's family to a member of the plaintiff's family, and the aggrieved party then gives in a receipt for the sum awarded as compensation. The Qur'añ is brought in, and everyone swears to keep the peace, and the incident is closed. Of course such a result requires long and troublesome negotiations, which are carried on under the supervision of a jirga, or assembly of chiefs and leading men, who settle the final terms to be submitted for the British officer's sanction.

Not only cases about women, but murders of other sorts, springing out of old feuds, disputes about boundaries, cattle thefts, rights in water, are similarly dealt with. This system is followed with Baloch tribes whether in our territory or partially independent, and as I had many years' experience in working it, I may be allowed to say that it has proved successful. To the late Sir Robert Sandeman the principal credit of this is due. We used to have a sort of parliament of tribes annually at Fort Munro in the Sulaimans, where the chiefs of the different jurisdictions with the officers in charge would meet to discuss all the cases which had arisen during the year; and when all had been settled, the proceedings would conclude with a general feasting and merrymaking. Scores of sheep would be slain and roasted by long lines of wood fires along the hill sides; and far 
through the night the minstrels would sing old songs of war and love round the fire; and the hill-men would dance in, circles, expanding and contracting with their flowing clothes and springy gait.

These dances of the mountaineers (known as $d r \bar{i} s$ ) are graceful and dignified, and are accompanied by a kind of chant, a Dom playing the drum sitting in the middle of the circle. Among the camel-men from the plains, the dances (jhamar) often take a comic and less dignified form. As the fun grows fast and furious the drummer becomes inspired with a fiendish excitement, and the circle breaks up into a number of groups; some dance in'couples and some singly, but all continue to revolve round the centre. Some sit down on the ground, squatting and hopping like frogs; some hop round on one foot, and all shout out "Whash en whash /" some making strange squeaking and piping noises with their mouths. But the hill-men do not indulge in these antics, but rather despise them.

The Doms belonging to the various tribes are much in evidence on these occasions, and are generally well rewarded by the chiefs. Sometimes other performers appear. I remember an old mountaineer, a Durkãni, who was celebrated for his powers as a mimic. He was known familiarly as "Gurkh," or Wolf, and had a son, a boy whom he called "Tholagh," or Jackal, who was very nearly as clever as his father: these men would personate some well-known characters among the Baloches, each impersonation being greeted with shouts of laughter. They would also imitate English officers, but this it was not easy for us to get a sight of ; they were shy, and perhaps the performances were not always complimentary. But once I witnessed a representation of the great Sandeman, or Sinneman, as they called him. He had a big bag of rupees in one hand, and a thick stick in the other, and gave money to some while he whacked others, which gave a popular idea of his method of combining conciliation with punishment. 
I have already alluded to the unwillingness to surrender refugees. This is a prominent feature in the tribal system. The $b \bar{a} u t$, or refugee, who flees for safety to the tribe, is sacred and must not be given up. The strength of this feeling is still very strong; the ballads contain many allusions to it. In one of those relating to Mir Chākar and Gohar, Bagar Jatoi calls out to Chākar, "When did a hero ever fail his refugees?" and proceeds to tell the story of Bibari and the lizard. Bibari sat in front of her hut and some boys came by. A lizard dropped out of a dwarf-palm and the boys pursued it, driving it into the house. Bibari stood in front of them, and begged them to spare the lizard, as it was her refugee; but they paid no attention to her and killed it. She went to her husband and said to him, "If you do not go to war on account of this lizard, I am your sister and you my brother," and he proceeded accordingly to take revenge.

Another case often quoted is the behaviour of Chäkar to the Lashäri women, already mentioned, and the conduct of Nodhbandagh towards Mir Chākar himself, when he mounted him on his own mare Phul, and allowed him to escape from the other Lasharis. A favourite story bearing on this point is that of Doda Gorgezh. ${ }^{1}$ A certain man who possessed a miraculous herd of cattle took refuge with Dodä, and died bequeathing his wife Sammi and the cattle to Dodä's protection; Doda sacrificed his life in the cause, and his tomb is shown at Garmäf, where he was killed. Dodä's wanderings in the mountains are vividly described in a poem attributed to his son Bäläch, who ultimately, with all the rest of the family, met his death at the hands of the Bulethis. One passage in this poem expresses the very spirit of the born mountaineer:

"The mountains are the Baloches' rampart, the clifs are better than an army; the lofty heights are our comrades, the pathless gorges our dearest

I See Ballich and the Bulethis. Folk-Lore, iv., 200.

VOL. XIII. 
friends. Our drink is from the flowing springs, our cup the leaf of the phish, our bed is the thorny bush, the hard ground our pillow. My white sandals are my steed, my son is the sharp arrow, my son-in-law the pointed dagger, my brethren the broad shield, my father the wide-wounding sword."

The same spirit is expressed in another poem :

"We will not dwell in the Indus plain; Phailāwagh will be our pasture. The salt stream of the Chāchar is our friend, it will taste sweet in our children's mouths, for these are the forts which keep the marauding Turk far from us."

So I am brought back again to the old legends and ballads with which I began, and I cannot do better than close with another quotation which gives the true spirit of all folklore. After relating the history of his tribe, the bard says :

"This is our track and story, this is the home of the true Rinds, a name exalted among tribes. If you do not believe it, no one has seen it with his eyes, there are no ancient documents or witnesses to attest it, but there are tales upon tales; everyone says titut'so it was."

M. Longworth Dames. 
恶

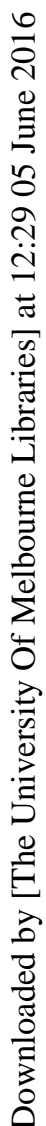

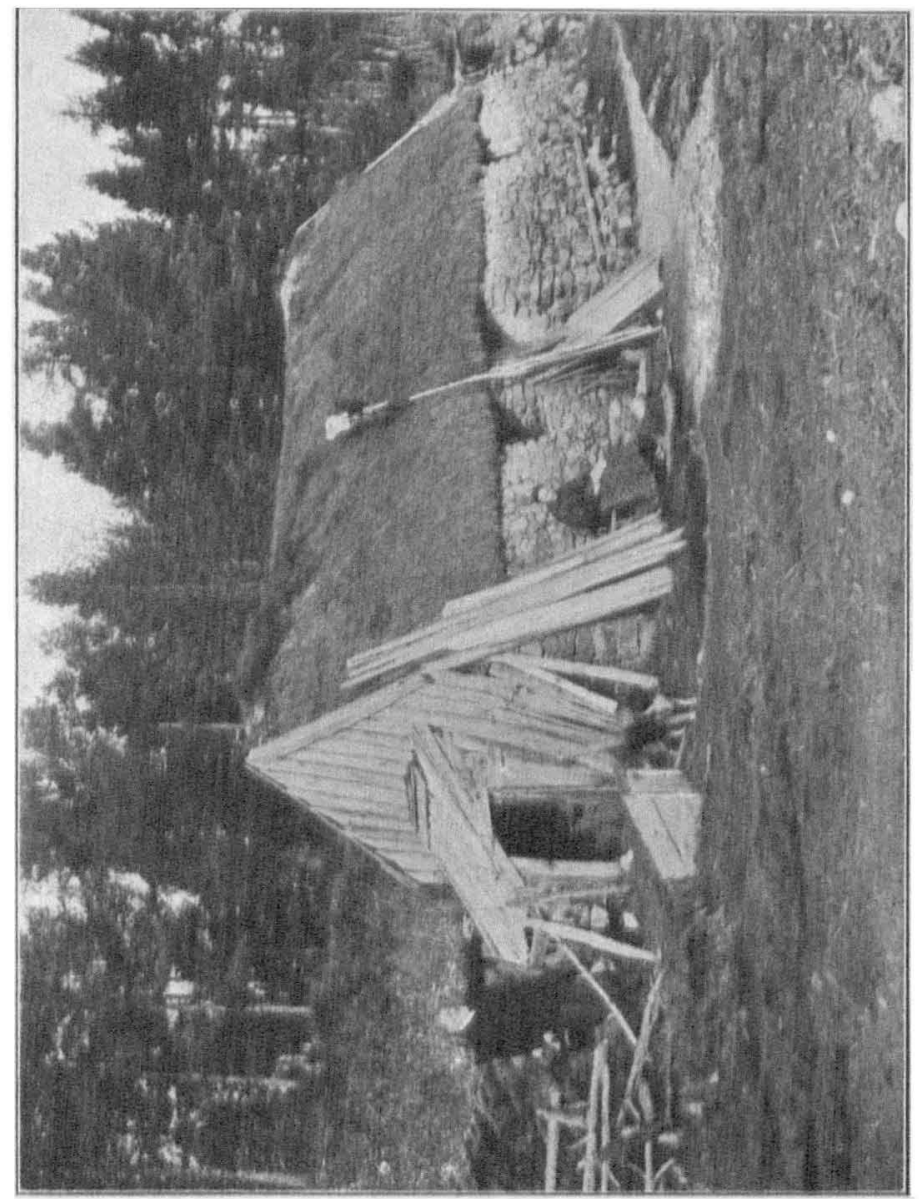

$\stackrel{\dot{m}}{z}$

山

$\frac{a}{T}$

点

$\sum_{0}$
$\frac{1}{\alpha}$
$\frac{1}{U}$

4

ס्

$=$

$\stackrel{I}{\frac{I}{3}}$

㟧 